\title{
HUMAN PAPILLOMAVIRUS AND ITS NATURE OF INFECTION: AN OVERVIEW
}

\section{SAYANTIKA CHAKRABORTY, RANIT DAS, VIJAY MISHRA*, NEHA SHARMA, NAVNEET KHURANA}

School of Pharmaceutical Sciences, Lovely Professional University, Phagwara, Punjab, India.

Email: vijaymishra2@gmail.com

Received: 12 December 2017, Revised and Accepted: 26 February 2018

\section{ABSTRACT}

Human papillomavirus (HPV) belonging to Papillomaviridae (family of Papillomavirus). HPV infection causes various types of disorders and diseases including cervical, vaginal, anal, penile, oropharyngeal, and lung cancer also cancer in head and neck along with some malignant and benign warts. HPV also found to be responsible for respiratory papillomatosis. Epidermodysplasia verruciformis, an orphan disease termed as tree man disease, is also occurred by the HPV infection. Vaccines show benefit nowadays. Some surgery and adjuvant therapy is also showing response in the treatment of HPV caused cancers. In this abstract, we summarized the types, structures, genomic organization, mode of transmission of the virus along with type of infections, and protection and modern treatment approaches.

Keywords: Human papillomavirus infection, Cancers, Human papillomavirus vaccines, Respiratory papillomatosis, Epidermodysplasia verruciformis.

(C) 2018 The Authors. Published by Innovare Academic Sciences Pvt Ltd. This is an open access article under the CC BY license (http://creativecommons. org/licenses/by/4. 0/) DOI: http://dx.doi.org/10.22159/ajpcr.2018.v11i6.24233

\section{INTRODUCTION}

The human papillomavirus (HPV) belongs to Papillomaviridae (family of papillomavirus) [1,2]. Taxonomically, Papillomaviridae is a virus family having the members of non-enveloped DNA viruses, on the whole called as Papillomaviruses [3]. Lots of species of papillomaviruses are there which are traditionally attributed as "types." Papillomaviruses can cause infection in most of the mammals [3] along with some other amniotes such as snakes, birds, and turtles [4-8].

\section{EVOLUTION OF PAPILLOMAVIRUS}

The word papilloma is the combination of two words that is Papilla and Oma. Papilla is a Latin word means a rounded small protuberance on an organ or on a part of body (ex-papilla on tongue) and Oma is also a Latin word stands for any abnormal growth such as tumors (ex-carcinoma). Hence, grossly we can say that the viruses which cause papilloma infection to humans are termed as HPV.

Papillomavirus evolution is presumed to be slower than many other types of , but this cannot be proved due to lack of experimental measurements. Codivergence with the host animal is one of the hypotheses in the evolution of papillomavirus. The other aspects of the evolution of papillomavirus are viral sorting, within host virus duplication, and adaptation of virus after switching of host [9]; for example, HPV16 reflected migration of human beings as it codiverged with human in whole earth showed variations in different regions $[10,11]$. The HPV-13 has a sequence which is closely similar a bonobo's (pygmy chimpanzees) papillomavirus [12] because HPV13 had changed a little bit for the past 6 or some more million years from when human and bonobos were diverged [11]

\section{MORPHOLOGY OF HPV}

The HPV is a DNA virus (non-enveloped). The DNA is having double strand which is arranged in circular manner. The DNA is having almost 8000 base pairs and packed with histone protein. The capsid is not covered with lipid membrane that is why it is termed as nonenveloped. The capsid (55-60 nm) is made up of proteins (L1 and L2). Geometrically, this capsid is regular and also symmetric-like icosahedrons. The capsomeres (unit of capsid) made up of proteins arranged in pentameric order. It also was observed that the capsid of many papillomavirus is made up of 72 capsomeres (Fig. 1) [13].

\section{GENOMIC ORGANIZATION AND GENE EXPRESSION}

The HPV has a circular double-stranded DNA as its genetic material. Its genome is comprises of two regions, early (E) and late (L). Early region has the coding regions which are commonly known as open reading frame (ORF) and the late region codes for 2 proteins, L1 and L2. These 2 proteins make its capsid. ORF is the region which codes for proteins or polypeptides. In spite of having two DNA strands, all the ORFs are situated on only one strand. The virus consists of six numbers of ORFs such as E1, E2, E4, E5, E6, and E7. Fig. 2 depicts the genetic organization of a papillomavirus [14].

Promoter site of its gene is activated only after infect the host cell. After doing infection to the host cell, the DNA of the papillomavirus goes into transcription (DNA to RNA). After transcription, primary mRNA is produce which contains all the ORFs. For these characteristics, this mRNA can code more than one protein or polypeptides (because it has six ORFs and all of those are able to do coding for proteins or polypeptides). This type of characterized RNA is generally known as polycistronic RNA [14].

This polycistronic RNA consists of two introns (non-coding sequence of DNA) and three exons (coding sequence of DNA). After the production of this RNA, it undergoes post-transcriptional modification in alteration mechanism more specifically splicing and produces multiple mRNAs. Splicing is a mechanism where the introns are removed. However, in HPV16, an intron of E6 ORF does not remove and endure intact after splicing. This intron codes E6 oncoprotein in translation and also expresses E7 oncoprotein. The viral genome s E2 ORF and enters into host genome, and thus, repression of E2 on both E6 and E7 is prevented. When this viral genome enters into host genome, the expressions obtained by E6 and E7 are increased, which help cells to proliferate and lead to malignancy [15].

The promoter site of late region (L) activates when DNA replication (DNA to DNA) takes place. After transcription, late region also produces polycistronic messenger RNA. This mRNA also consists of three exons and two introns. In transcription process, this mRNA codes L1 and L2 protein which is essential for the formation of capsid of this virus. Post- 
transcriptional modification in late region is also splicing, and in this case, it is regulated by some splicing factors of host and cis-elements of RNA.

The E6 ORF codes $\mathrm{E} 6$ protein (sometimes $\mathrm{E} 7$ also). This protein attached with $\mathrm{p} 53$ protein and inactivates it. The $\mathrm{p} 53$ protein is coded by $\mathrm{p} 53$ gene (tumor suppressor gene and also a negative regulator for cell cycle). The E6 protein makes p53 protein to bind with ubiquitin (a regulatory protein) and degrades $\mathrm{p} 53$ protein by ubiquitin ligase pathway and leads $\mathrm{p} 53$ for lyses by proteasome. The p 21 is another protein under the control of p53 which inactivates cyclin D/Cdk4 complex (a positive regulator of cell cycle) and prevents phosphorylation of $\mathrm{Rb}$ protein (a protein holds the cell cycle in check while it is hypophosphorylated). As a result, a cell gets arrested. The p53 protein also plays a key role in mitochondrial pathway of apoptosis (programmed cell death). When DNA gets damaged, p53 protein plays most important role in the formation of apoptosome, caspase 9, and then caspase 3 and leads to cell death. Hence, by inactivating p53 protein, E6 protein inhibits cell death as well as increases cell proliferation [15].

\section{VIROLOGY}

The HPV cannot bind with living cells. It can only infect epithelial cell as it is dead cell. More specifically, only the basal cells of stratified epithelial tissue are infected by HPV. This virus replicates only in this tissue. This virus infects the host cell (epithelial) by microsized abrasions or other trauma in epithelial tissue, and as a result, some segments of basal membrane gets exposed and the virus can easily enters into host cell [16]. As this virus is a non-enveloped virus, it induces antibody production into host organism. However, those antibodies cannot neutralize the viruses because they still remain in the basement membrane as well as cell surface. The keratinocytes of stratified epithelium tissue is infected by this virus. HPV has laminis and alpha integrins receptors, which helps it to enter into host keratinocytes by endocytosis (caveolin-mediated endocytosis and/or clathrin-mediated endocytosis). After entering into keratinocyte, the virus genome is moved to the nucleus of keratinocytes, but the transportation pathway is still unknown. After that, it makes 10-200 numbers of its copy per host cell. This virus cannot do oxidative lyses of host cell, instead of that they release after the degeneration of the desquamated cells [15]. Papillomavirus can survive without host for many months in a low temperature, which indicates that HPV infection can also be caused by other than skin contact like sharing objects [15].

\section{MODE OF TRANSMISSION}

The HPV infection occurs by the HPV [1]. Some of the HPV infection does not show any symptoms and can be cured spontaneously [16]. This infection causes warts or sometimes precancerous lesions. This kind of precancerous lesions can lead to cancers, for example, vaginal, anal, cervical, oropharyngeal, and penile cancers [17]. HPV18 and HPV16 are found to be responsible in $70 \%$ of cases of cervical cancers, whereas HPV11 and HPV6 are responsible for respiratory papillomatosis and genital warts [16]. There are various ways by which HPV infections can occur (Table 1). These are summarized as follows.

\section{Sexual contact}

Sexual contact is one of the major risk factors for HPV infections [18]. From the known 120 species of papillomaviruses, 51 types along with their subtypes are found to be responsible for the infection of mucosa layers of genital areas [19]. Among them, 15 types are grouped as "high risk" such as $18,31,16,33,39,35,52,51,45,58,59,56,82,68$, and 73. The 3 types are categorized as "moderate risk" such as 66,26 , and 53. The 12 types are grouped as "lower risk" such as $81,61,11,70$, 40, 44, 6, 43, 72, 54, CP6108, and 70 [20]. First sexual intercourse in an early age, multiple sexual partners, cunnilingus, and/or fellatio with multiple partners and unhygienic habits are the main causes of HPV infection [16].

\section{PERINATAL}

During childbirth, HPV can be transmitted to child from the mother. However, in this case, the infection does not show any appearance quickly as this virus can hide them for a longer time. Juvenile onset recurrent respiratory papillomatosis (JORRP) is produced by HPV11 and HPV6 in neonates. The JORRP is seen in 2 neonates among $1,000,000$ neonates, and in this term, it is said that it is rare disease.

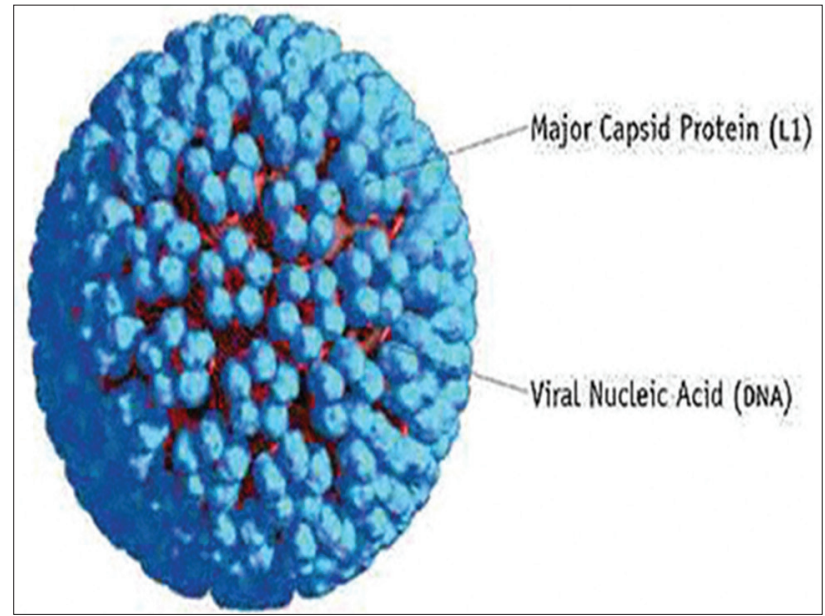

Fig. 1: The three-dimensional structure of a general type of Papilloma virus

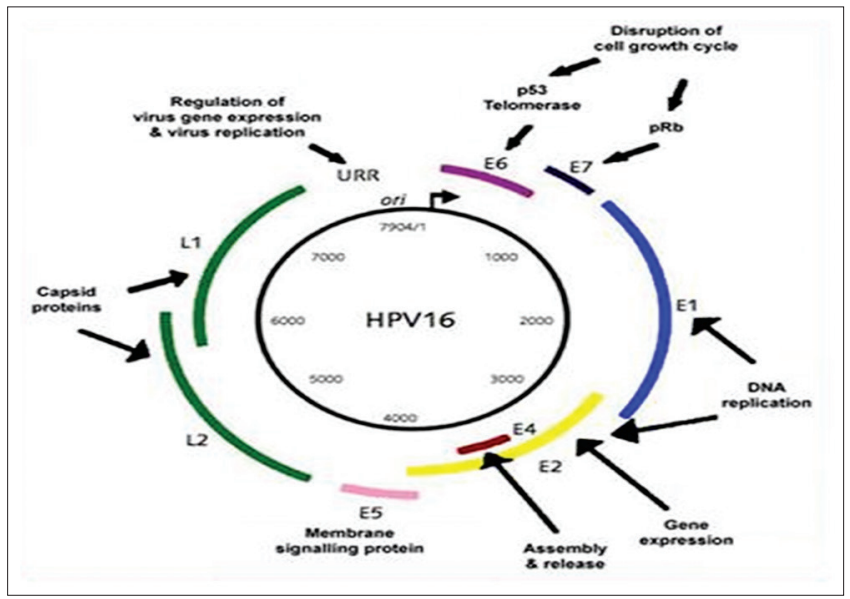

Fig. 2: Genetic organization of Papilloma virus

Table 1: Risk factors, infection, transmission mode, severity, and preventive measures of HPV

\begin{tabular}{|c|c|c|c|c|}
\hline Risk factors & Infection & Transmission mode & Severity & Preventive measure \\
\hline $\begin{array}{l}\text { Multiple sexual partners, feeble } \\
\text { immunity system, age, broken } \\
\text { skin, skin contact, tobacco use }\end{array}$ & $\begin{array}{l}\text { Cancers } \\
\text { (cervical, genital, oropharyngeal, } \\
\text { lungs, head and neck), warts } \\
\text { (common, planter, flat, } \\
\text { periangular), genital warts, } \\
\text { respiratory papillomatosis, } \\
\text { Epidermodysplasia verruciformis }\end{array}$ & $\begin{array}{l}\text { Sexual contact, } \\
\text { perinatal, blood, } \\
\text { hands, surgery, } \\
\text { sharing objects }\end{array}$ & $\begin{array}{l}\text { In } 2012 \text {, worldwide, } 5,30,000 \\
\text { new cases of cervical cancer } \\
\text { were reported. Alongside, } \\
270000 \text { incident of mortality } \\
\text { caused by cervical cancer } \\
\text { every year }\end{array}$ & $\begin{array}{l}\text { Vaccines, condoms, } \\
\text { disinfectant }\end{array}$ \\
\hline
\end{tabular}


However, the rate of JORRP increases if the mother has genital warts during childbirth though it is very less $(<1 \%)$ [21].

\section{Blood}

Previously, it was believed that HPV infection cannot transmit by blood. However, in 2005, a study was done in 57 pediatric patients (naive in sexual contact) who were transfusion acquired or vertical HPV infected, and among 8 of them, HPV16 was detected in their blood samples [22]. Although in blood, the existence of the DNA of HPV cannot prove that the person is infected by HPV. To prove this, in 2009, a test was done with 180 healthy male's blood sample and 15 among the samples were found one or more than one type of HPV [23]. The conclusion about this topic is yet not decided whether HPV is transmitted through blood or not [24].

\section{Hands}

The HPV infection can be spread among sexual partners or the same person through their genitals and hands. A study done with 25 couples for 7 months tested on their hands and genitals. The outcome of this study demonstrated that 2 among 25 couples infected by HPV (high risk). The hands of females infected for the genital infections of the men. In 2 couples, the hands of women infected men's genitals. In one couple, the man's hand is infected by this woman's genitals. In 2 couples, each of them infects their own hand [25]. This experiment showed that hand was not the primary source of HPV infection, but hands played a key role in this infection. However, non-sexual contact by hand had very little or generally no role in this HPV infection.

\section{Sharing object}

The object which is contaminated with HPV can cause HPV infection in case of sharing [26]. Except sexual contact, other possible routes are not common for genital HPV infection in female. However, sharing common things such as toilet seat cannot cause HPV infection.

\section{Surgery}

It has been documented that HPV infection can be spread by inhalation viral noxious substance by any person in the surgery room during laser ablation on condyloma or electrocautery. A surgeon infected by HPV during laser ablation on anogenital condyloma can suffer from laryngeal papillomatosis [27].

\section{TYPES OF INFECTIONS CAUSED BY HPV}

\section{Cancer}

Cancer in vagina, anus, vulva, penis, and most important in cervix is cased due to HPV infections [16,17]. The HPV16, HPV18, HPV31, and HPV45 are known to be highly risky for all the types of previously said cancers. Some infected patient's immune system does not respond after this infection and this will enhance the growth of cancers. Additional effects such as cigarette smoking enhance the chance of getting cancer associated with HPV [28]. The types of cancers associated with HPV infections are as follows.

\section{- Cervical cancer}

HPV infection is the foremost cause of cervical cancer, which is the leading cancer in India and second utmost common cancer worldwide. Approximately, all the types of cervical cancers are caused due to the infection of HPV. In $70 \%$ of cervical cancers, the HPV18 and HPV16 infections are found to be responsible [16]. About 41-54\% cervical cancers are found to be occurring for the HPV16, the one strain which is mostly malignant [29]. HPV16 is also responsible for anal, vaginal, head and neck, vulvar, and also penile cancers [30]. In general, in cervical cancer, the rate of transformation of normal cells into cancerous cells is relatively slower. The persons infected with HPV more than a decade or a much longer duration are more prone to having cervical cancers $[21,31]$.

\section{- Genital cancer}

Penile cancer and anal cancer also caused by HPV when transmitted sexually. The risk for getting anal cancer with the HPV is higher for the bisexual and homosexual men [32,33]. However, one study showed that there was no difference between homosexual men and heterosexual men in terms of HPV infection rate [33].

\section{- Oropharyngeal cancer}

Oral HPV infection causes oropharyngeal cancer. This is also termed as HPV+OPC (HPV16+ oropharyngeal cancer). This type of cancer is also relatively slowly showed symptoms such as cervical cancers, and risk is shown after 15 years from when that person infected by HPV [34]. Tobacco increases the risk of retrogression of disease with HPV+POC patients [35].

\section{- Lung cancer}

The HPV can cause malignant as well as benign tumors in the upper part of respiratory tract. Antibodies for HPV are found in many cases of lung cancers [36]. The expression of the proteins (structural) of HPV shows the presence of HPV in bronchial cancers in in vitro and immunohistochemistry studies [37].

\section{- Cancer on head and neck}

The HPV16 and HPV18 are found to be responsible for head-and-neck cancers. HPV infection spread by sexual contacts is increased the risk of oral cancers, tonsil cancers, oropharyngeal cancer as well as upper throat and mouth cancer in non-smokers also [38]. Oropharyngeal cancer caused by HPV termed as HPV+OPC (HPV16+ oropharyngeal cancer) [34].

\section{WARTS}

Warts are generally found with all the types of HPV infections. Noncancerous warts are very common in people. HPV2, HPV27, and HPV57 cause warts while types 2,1 , and 63 do not cause warts [39]. The types of warts are common warts (found in feet, hands, knees, and elbows), plantar warts (found in feet soles), flat warts (found in foreheads, faces, and arms), and periangular warts (found in fingernails around cuticles and nails also).

Genital warts associated with HPV are one of the very usual sexually transmitted diseases. More than $90 \%$ of cases of the all types of genital warts are caused by HPV6 and HPV11 [40]. Infection in anus and genitals caused by HPV (40 types) is transmitted by sexual activities [41]. This type of infection leads to warts in genital areas. It is found that most of the population gets HPV infection at least once in their life. It is not obvious that genital warts lead to cancers, some cured without any kind of medications or attentions [41].

\section{RESPIRATORY PAPILLOMATOSIS}

The presence of warts in respiratory tract including larynx or other parts is termed as respiratory papillomatosis [21]. HPV6 and HPV11 cause respiratory papillomatosis. Inhalation is one of the aspects for the spreading of respiratory papillomatosis. A surgeon infected by HPV during laser ablation on anogenital condyloma can suffer from laryngeal papillomatosis [27]

\section{EPIDERMODYSPLASIA VERRUCIFORMIS}

Epidermodysplasia verruciformis is also termed as tree man disease and is an abnormality in autosomal recessive gene along with HPV infection leads to high risk skin carcinoma [42]. The patient's immune system fails to check HPV and produce keratin in an excess level, which causes horns in the skin.

\section{PREVENTIVE MEASURES}

\section{Vaccines}

Three types of vaccines are made to prevent HPV infections. They are Gardasil 9, cervarix, and Gardasil. They are able to protect form HPV16 and HPV18, while Gardasil (a recombinant vaccine) is able to protect form HPV6 and HPV11 also. Cervarix (bivalent type) is produced by VLP (virus like particles which are look like virus but do not contain viral 
genome) from the protein found in capsid (L1). The Gardasil 9 is able to protect from HPV16, HPV18, HPV31, HPV45, HPV52, HPV58, HPV6, and HPV11; hence, above $90 \%$ of genital cancers (cervical, anal, vaginal, and vulvar cancers) can be protected with the help of these vaccines [43]. These vaccines show very little effects on the women who have already exposed to HPV16 and HPV18. Hence, women who are sexually naives are recommended for vaccination [44].

\section{Condoms}

The CDCP suggests that the use of condoms is beneficial to decrease the risk associated to the HPV infection. Female condoms are found to be much more acceptable in terms of the reduction of HPV contact. However, condom cannot give too much protection as HPV can transmit through any area which is not covered by condoms like any mucosal surface or infected area of skin [45].

\section{Disinfectants}

This virus can be killed by some disinfectant though it is very difficult to kill it. Exposed it to $90 \%$ ethanol (for $1 \mathrm{~min}$ ), 30\% savlon, $2 \%$ glutaraldehyde, and $1 \%$ sodium hypochlorite can be beneficial. This virus can be demolished at $100^{\circ} \mathrm{C}$ though it is resistance in temperature and drying. It can also be killed by ultraviolet radiations [46].

\section{CONCLUSION AND FUTURE PERSPECTIVES}

Treatment in HPV infection is still not available [47]. Only by giving vaccine, we can prevent HPV infection but the persons already exposed to HPV cannot be cured till now. Recent study shows that HPV-positive oropharyngeal cancers can be cured with the help of surgery as well as adjuvant therapy [48]. Antiretroviral therapy is also found to be helpful in the case of anal and cervical cancers [49].

The HPV infection is one of the major concerns nowadays. The virus can be spread by very common routes such as hand contact, sharing objects, sexual contacts, blood, and most surprisingly through inhalation also [50]. Protection from this virus is available only by vaccination. On the clinical trials (phase II) of Cervarix ${ }^{\mathrm{TM}}$, the efficacy of preventing HPV18 and 16 infection was $92 \%$ while efficacy in the prevention of obstinate infection was $100 \%$. On the other hand, the efficacy of preventing HPV $6,11,16$, and 18 with Gardasil ${ }^{\mathrm{TM}}$ was $90 \%$ in Phase II and $100 \%$ (for HPV 16 and 18) in phase III clinical trial [51,52]. However, vaccination also associated with many limitations like it should be given within 1319 before any kind of sexual exposure though it can be spread through hand contact also. All kind of HPV cannot protect by this vaccines. Only a few can be protected. The use of condoms shows very little protection. Treatment is also unavailable till date. However, recent studies show some hope to as through surgery and adjuvant therapy or antiretroviral therapy is found to cure HPV-positive oropharyngeal, anal, and cervical cancers.

\section{AUTHORS CONTRIBUTIONS}

The authors contributed equally to this work.

\section{CONFLICT OF INTEREST}

The authors declare no conflict of interests related to this paper.

\section{REFERENCES}

1. Milner DA. Diagnostic pathology: Infectious diseases. Philadelphia, PA: Elsevier Health Sciences; 2015.

2. Centers for Disease Control and Prevention (CDCP). What is HPV? Available from: https://www.cdc.gov/hpv/parents/whatishpv.html. [Last retrieved on 2017 Aug 10].

3. de Villiers EM, Fauquet C, Broker TR, Bernard HU, zur Hausen H. Classification of papillomaviruses. Virology 2004;324:17-27.

4. Herbst LH, Lenz J, Van Doorslaer K, Chen Z, Stacy BA, Wellehan JF Jr, et al. Genomic characterization of two novel reptilian papillomaviruses, Chelonia mydas papillomavirus 1 and caretta caretta papillomavirus 1 . Virology 2009;383:131-5.

5. Drury SE, Gough RE, McArthur S, Jessop M. Detection of herpesvirus- like and papillomavirus-like particles associated with diseases of tortoises. Vet Rec 1998;143:639.

6. Lange CE, Favrot C, Ackermann M, Gull J, Vetsch E, Tobler K. Novel snake papillomavirus does not cluster with other non-mammalian papillomaviruses. Virol J 2011;8:436.

7. Gottschling M, Göker M, Stamatakis A, Bininda-Emonds OR, Nindl I, Bravo IG, et al. Quantifying the phylodynamic forces driving papillomavirus evolution. Mol Biol Evol 2011;28:2101-13.

8. Ho L, Chan SY, Burk RD, Das BC, Fujinaga K, Icenogle JP, et al. The genetic drift of human papillomavirus Type 16 is a means of reconstructing prehistoric viral spread and the movement of ancient human populations. J Virol 1993;67:6413-23.

9. Calleja-Macias IE, Villa LL, Prado JC, Kalantari M, Allan B, Williamson AL, et al. Worldwide genomic diversity of the high-risk human papillomavirus Types $31,35,52$, and 58 , four close relatives of human papillomavirus Type 16. J Virol 2015;79:13630-40.

10. Van Ranst M, Fuse A, Fiten P, Beuken E, Pfister H, Burk RD, et al. Human papillomavirus Type 13 and pygmy chimpanzee papillomavirus Type 1: Comparison of the genome organizations. J Virol 1992;190:587- 96.

11. Rayment I, Baker TS, Caspar DL, Murakami WT. Polyoma virus capsid structure at 22.5 A resolution. Nature 1982;295:110-5.

12. Zheng ZM, Baker CC. Papillomavirus genome structure, expression, and post-transcriptional regulation. Front Biosci 2006;11:2286-302.

13. Tang S, Tao M, McCoy JP, Zheng ZM. The E7 oncoprotein is translated from spliced E6* I transcripts in high-risk human papillomavirus Type 16-or Type 18-positive cervical cancer cell lines via translation reinitiation. J Virol 2006;80:4249-63.

14. Schiller JT, Day PM, Kines RC. Current understanding of the mechanism of HPV infection. Gynecol Oncol 2010;118:S12-7.

15. Joyce JG, Tung JS, Przysiecki CT, Cook JC, Lehman ED, Sands JA, et al. The L1 major capsid protein of human papillomavirus Type 11 recombinant virus-like particles interacts with heparin and cellsurface glycosaminoglycans on human keratinocytes. J Biol Chem $1992 ; 274: 5810-22$

16. World Health Organization (WHO). Human Papillomavirus (HPV) and Cervical Cancer. Available from: http://www.who.int/news-room/factsheets/detail/human-papillomavirus-(hpv)-and-cervical-cancer. [Last retrieved on 2016 Aug 10].

17. Ljubojevic S, Skerlev M. HPV-associated diseases. Clin Dermatol 2014;32:227-34

18. Burchell AN, Winer RL, de Sanjosé S, Franco EL. Epidemiology and transmission dynamics of genital HPV infection. Vaccine 2006;24 Suppl 3:52-61.

19. Schmitt M, Depuydt C, Benoy I, Bogers J, Antoine J, Arbyn M, et al. Prevalence and viral load of 51 genital human papillomavirus types and 3 subtypes. Int J Cancer 2013;132:2395-403.

20. Muñoz N, Bosch FX, de Sanjosé S, Herrero R, Castellsagué X, Shah KV, et al. Epidemiologic classification of human papillomavirus types associated with cervical cancer. N Engl J Med 2003;348:518-27.

21. Sinal SH, Woods CR. Human papillomavirus infections of the genital and respiratory tracts in young children. Semin Pediatr Infect Dis 2005;16:306-16.

22. Bodaghi S, Wood LV, Roby G, Ryder C, Steinberg SM, Zheng ZM, et al. Could human papillomaviruses be spread through blood? J Clin Microbiol 2005:43:5428-34

23. Chen AC, Keleher A, Kedda MA, Spurdle AB, McMillan NA, Antonsson A, et al. Human papillomavirus DNA detected in peripheral blood samples from healthy Australian male blood donors. J Med Virol 2009;81:1792-6.

24. Krueger H, Stuart G, Gallagher R, Williams D. HPV and Other Infectious Agents in Cancer: Opportunities for Prevention and Public Health. New York (NY): Oxford University Press; 2010.

25. Hernandez BY, Wilkens LR, Zhu X, Thompson P, McDuffie K, Shvetsov YB, et al. Transmission of human papillomavirus in heterosexual couples. Emerg Infect Dis 2008;14:888-94.

26. Tay SK. Genital oncogenic human papillomavirus infection: A short review on the mode of transmission. Ann Acad Med Singapore 1995;24:598-601.

27. Watson RA. Human papillomavirus: Confronting the epidemic-A urologist's perspective. Rev Urol 2005;7:135-44.

28. Alam S, Conway MJ, Chen HS, Meyers C. The cigarette smoke carcinogen benzo[a]pyrene enhances human papillomavirus synthesis. J Virol 2008;82:1053-8.

29. Baseman JG, Koutsky LA. The epidemiology of human papillomavirus infections. J Clin Virol 2005;32 Suppl 1:S16-24.

30. Bolt J, Vo QN, Kim WJ, McWhorter AJ, Thomson J, Hagensee ME, et al. The ATM/p53 pathway is commonly targeted for inactivation in 
squamous cell carcinoma of the head and neck (SCCHN) by multiple molecular mechanisms. Oral Oncol 2005;41:1013-20.

31. Greenblatt RJ. Human papillomaviruses: Diseases, diagnosis, and a possible vaccine. Clin Microbiol Newslett 2005;27:139-45.

32. Frisch M, Smith E, Grulich A, Johansen C. Cancer in a populationbased cohort of men and women in registered homosexual partnerships. Am J Epidemiol 2003;157:966-72.

33. Gaither TW, Truesdale M, Harris CR, Alwaal A, Shindel AW, Allen IE, et al. The influence of sexual orientation and sexual role on male grooming-related injuries and infections. J Sex Med 2005;12:631-40.

34. Chaturvedi A, Gillison ML. Human papillomavirus and head and neck cancer. In: Olshan AF, editor. Epidemiology, Pathogenesis, and Prevention of Head and Neck Cancer. $1^{\text {st }}$ ed. New York: Springer; 2010.

35. Maxwell JH, Kumar B, Feng FY, Worden FP, Lee JS, Eisbruch A, et al. Tobacco use in human papillomavirus-positive advanced oropharynx cancer patients related to increased risk of distant metastases and tumor recurrence. Clin Cancer Res 2010;16:1226-35.

36. American Association for Cancer Research (AACR). Lung Cancer Risk Rises in the Presence of HPV Antibodies; 2011. Available from: http:// www.aacr.org.

37. Syrjänen K, Syrjänen S, Kellokoski J, Kärjä J, Mäntyjärvi R. Human papillomavirus (HPV) Type 6 and 16 DNA sequences in bronchial squamous cell carcinomas demonstrated by in situ DNA hybridization. Lung 1989; $167: 33-42$.

38. D’Souza G, Kreimer AR, Viscidi R, Pawlita M, Fakhry C, Koch WM, et al. Case-control study of human papillomavirus and oropharyngeal cancer. N Engl J Med 2007;356:1944-56.

39. Koning MN, Quint KD, Bruggink SC, Gussekloo J, Bouwes Bavinck JN, Feltkamp MC, et al. High prevalence of cutaneous warts in elementary school children and ubiquitous presence of wart-associated HPV on clinically normal skin. Br J Dermatol 2014;172:196-201.

40. Greer CE, Wheeler CM, Ladner MB, Beutner K, Coyne MY, Liang H, et al. Human papillomavirus (HPV) type distribution and serological response to HPV type 6 virus-like particles in patients with genital warts. J Clin Microbiol 1995;33:2058-63.

41. World Health Organization (WHO). World Cancer Report 2014. Ch. 5,12. Geneva: World Health Organization; 2014.
42. Lazarczyk M, Pons C, Mendoza JA, Cassonnet P, Jacob Y, Favre M, et al. Regulation of cellular zinc balance as a potential mechanism of EVER-mediated protection against pathogenesis by cutaneous oncogenic human papillomaviruses. J Exp Med 2008;205:35-42.

43. Food and Drug Administration (FDA). Available from: http://www.fda. gov/NewsEvents/Newsroom/PressAnnouncements/ucm426485.htm. [Last retrieved on 2016 Jan 30].

44. Human Papillomavirus Epidemiology and Prevention of VaccinePreventable Diseases. Available from: http://www.Cdc.gov. [Last retrieved on 2016 Jan 30].

45. CDC. Condom Effectiveness-Male Latex Condoms and Sexually Transmitted Diseases. Centers for Disease Control and Prevention (CDC); 2009. Available from: https://www.cdc.gov/condomeffectiveness/docs/ condoms and stds.pdf. [Last retrieved on 2016 Jan 30].

46. Pathogen Safety Data Sheet (PSDS)-Infectious Substances. Available from: http://www.phac-aspc.gc.ca/lab-bio/res/psds-ftss/papillome-eng. php. [Last retrieved on 2016 Jan 30].

47. Centers for Disease Control and Prevention (CDC). Genital HPV Infection Fact Sheet; 2008. Available from: https://stacks.cdc.gov/view/ cdc/26043. [Last retrieved on 2016 Jan 30].

48. Kaczmar JM, Tan KS, Heitjan DF, Lin A, Ahn PH, Newman JG, et al. HPV-related oropharyngeal cancer: Risk factors for treatment failure in patients managed with primary transoral robotic surgery. Head Neck 2016;38:59-65.

49. Bratcher FL, Sahasrabuddhe VV. R Tehvieew impact of antiretroviral therapy on HPV and cervical intraepithelial neoplasia: Current evidence and directions for future research. Infect Agents Cancer 2010;5:8.

50. Praveena P, Jethinlalkhosh JP, Doss VA. Pharmacological evaluation of antineoplastic activity of hydroethanolic extract of unripe fruit of Carica papaya linn using animal model. Asian J Pharm Clin Res 2017;10:179.

51. Grimes JL. HPV vaccine development: A case study of prevention and politics. Biochem Mol Biol Educ 2006;34:148-54.

52. Gunalan G, Krishnamurthy V. Impact of radiotherapy on oxidative stress in neutrophils of cervical cancer patients. Asian J Pharm Clin Res 2012;5:65. 